University of Nebraska - Lincoln

DigitalCommons@University of Nebraska - Lincoln

May 2018

\title{
Mensurative Approach to Examine Potential Interactions Between Age-0 Yellow Perch (Perca flavescens) and Bluegill (Lepomis macrochirus)
}

Mark A. Kaemingk

University of Nebraska - Lincoln, mkaemingk2@unl.edu

David W. Willis

Follow this and additional works at: https://digitalcommons.unl.edu/natrespapers

Part of the Natural Resources and Conservation Commons, Natural Resources Management and Policy Commons, and the Other Environmental Sciences Commons

Kaemingk, Mark A. and Willis, David W., "Mensurative Approach to Examine Potential Interactions Between Age-0 Yellow Perch (Perca flavescens) and Bluegill (Lepomis macrochirus)" (2018). Papers in Natural Resources. 706.

https://digitalcommons.unl.edu/natrespapers/706

This Article is brought to you for free and open access by the Natural Resources, School of at DigitalCommons@University of Nebraska - Lincoln. It has been accepted for inclusion in Papers in Natural Resources by an authorized administrator of DigitalCommons@University of Nebraska - Lincoln. 


\title{
Mensurative approach to examine potential interactions between age-0 yellow perch (Perca flavescens) and bluegill (Lepomis macrochirus)
}

\author{
Mark A. Kaemingk • David W. Willis
}

Received: 1 February 2012/ Accepted: 19 June 2012/Published online: 5 July 2012

(C) Springer Science+Business Media B.V. 2012

\begin{abstract}
Bluegill (Lepomis macrochirus) and yellow perch (Perca flavescens) populations are often sympatric in the Great Plains region of the U.S.A. and portions of Canada; however, very little attention has been given to potential interactions between these species for available resources, especially during the early life stages. Relationships between age- 0 bluegill and yellow perch growth and relative abundance were explored across multiple lakes and years within the Nebraska Sandhill region, USA. In addition, four habitat patch types (open water, Phragmites spp., Typha spp., Scirpus spp.) were sampled for age-0 bluegill and yellow perch, and food habits were examined for each species during August, September, and October of 2009 in one of these lakes. Age-0 yellow perch growth was negatively related to age- 0 bluegill relative abundance across a spatiotemporal scale. Age-0 bluegill and yellow perch exhibited similar habitat use (moderate-high overlap), but generally consumed different important and dominant prey taxa (bluegill consumed both macroinvertebrates-56\% and zooplankton-44\%, while yellow perch consumed more zooplankton-66\%), which resulted in low overall diet overlap between species. Previous research indicates that age- 0 yellow perch diet
\end{abstract}

Handling Editor: Thomas Mehner.

M. A. Kaemingk $(\bowtie) \cdot$ D. W. Willis

Department of Natural Resource Management, South Dakota State University, Brookings, SD 57007, USA

e-mail: mark.kaemingk@sdstate.edu ontogeny often results in feeding predominately on macroinvertebrates and positively selecting them (and avoiding zooplankton prey) at sizes observed in our study. Therefore, yellow perch growth rates may be compromised by the presence of bluegill because of the need to consume less energetically profitable prey items such as zooplankton.

Keywords Bluegill - Yellow perch · Competition · Habitat · Diet

\section{Introduction}

Interactions within and among species can result in intraspecific and interspecific competition, respectively, which are important drivers of population dynamics. These competitive interactions can lead to decreased growth and elevated mortality rates and can ultimately result in decreased fitness within a species (Kennedy and Strange 1986; Hearn 1987). The mechanism or avenue of competition between two species for food and available habitat usually exists in two forms. These include (1) interference, where one species aggressively excludes another less aggressive species, which results in reduced growth rates or increased mortality of the less aggressive species (Holbrook and Schmitt 2002; Mills et al. 2004), and (2) exploitative, where both species have equal access to the available resources, but one species may be more efficient or exists in higher density and thus has 
an advantage, but is not administered through aggressive tactics (Mittelbach 1988; Hixon and Jones 2005).

Eurasian perch (Perca fluviatilis) and roach (Rutilus rutilus), which are often found in sympatry, can compete for available resources, especially food during times of low resource availability (Persson 1983c; Bergman 1990). Roach are often favored in systems with low food availability due to their ability to prey on a broad range of diet items at a lower trophic level such as algae, detritus, and smaller zooplankton compared to Eurasian perch, which are strictly carnivorous (i.e., invertebrates and small fishes; Persson 1983a, b). This competitive advantage becomes more substantial in populations where roach exist in higher densities than Eurasian perch (Persson 1983c; Bergman 1990).

A similar interaction situation as that found between Eurasian perch and roach could exist between bluegill (Lepomis macrochirus) and yellow perch (Perca flavescens) populations. Because populations of these two species are often sympatric and are common within the Great Plains region of the U.S.A. and portions of Canada, the potential for resource competition may exist. Despite this information, few studies have addressed this aspect (but see Schoenebeck and Brown 2010), and to our knowledge, no studies are available that examine these relationships during the later age-0 bluegill and yellow perch life stage (but see Kaemingk et al. 2012, during the early age-0 life stage). Given that recruitment is often thought to be established during the first year of life and given high interannual variability in recruitment for many fishes (Ludsin and DeVries 1997; Santucci and Wahl 2003), examination of competitive species interactions during this time period is crucial for our understanding of recruitment and will ultimately provide valuable information for ecologists and fisheries managers.

Our objectives for this study were to examine interactions between age- 0 bluegill and age-0 yellow perch for habitat and food resources. In addition, we wanted to determine whether there was any evidence for interspecific competition between these two species for these resources. We hypothesized that interactions between age- 0 yellow perch and bluegill for available habitat and prey resources would be minimal (i.e., low resource overlap). Age-0 yellow perch would most likely utilize open-water habitats (rather than emergent vegetation) and consume primarily macroinvertebrates (rather than zooplankton) during late summer or fall based on previous research (Whiteside et al. 1985; Wu and Culver 1992; Graeb et al. 2006). Alternatively, we expected age-0 bluegill to associate with emergent vegetation (rather than open water) and consume both zooplankton and macroinvertebrates (see Mittelbach 1981; Mittelbach 1984).

\section{Methods}

Two common approaches have been used to evaluate interspecific interactions between potential competitors: a manipulative approach (e.g., laboratory setting in a controlled environment or controlled field study) and a mensurative approach (e.g., documenting patterns in the field). Each approach has strengths and weaknesses when attempting to highlight relationships between species for the use of a common resource (Tilman 1987). A manipulative approach allows the resources and abundances of each species of interest to be modified to reflect different scenarios (Connell 1983; Tilman 1987). These experiments can often be replicated, and mechanisms of competition may be isolated; however, this approach can lack reality or what is naturally occurring in the field in an attempt to parse out important variables (Carpenter 1996; Carpenter 1999). Alternatively, a mensurative approach is more descriptive of reality but is often masked with interference from a multitude of uncontrolled variables acting on the species of interest (Drenner and Mazumder 1999). Thus, mensurative studies can limit inferences on the exact mechanisms or degree of competition between species, but provide valuable insight as to whether there is any evidence of competition in the natural environment (Gabler and Amundsen 1999; Wheeler and Allen 2003; Raborn et al. 2004; Jang et al. 2006). Therefore, we chose to take a mensurative approach to evaluate potential interactions between age-0 bluegill and yellow perch because no other studies have examined this to date, and therefore, these results will provide baseline information for future studies.

\section{Study area}

Clear, Dewey, Pelican, Watts, and West Long lakes were sampled and are all located within the Valentine National Wildlife Refuge in north-central Nebraska, 
USA. Lakes ranged from 25 to 332 ha in surface area and are relatively shallow (mean depth 1.3-2.1 m). The fish assemblage in each lake is relatively simple consisting mainly of bluegill, yellow perch, largemouth bass (Micropterus salmoides), northern pike (Esox lucius), black bullhead (Ameiurus melas), and common carp (Cyprinus carpio).

Pelican Lake (sampled for both objectives) and the other lakes sampled are primarily dominated by three emergent plant types, including Phragmites spp., Scirpus spp., and Typha spp. (hereafter referred to as Phragmites, Scirpus, and Typha). Using the methods outlined by Paukert et al. (2002), emergent vegetation coverage during late July 2009 in Pelican Lake was $8.5 \%$ for Phragmites, $15.5 \%$ for Scirpus, and $7.0 \%$ for Typha. The remaining portion of the lake was classified as submergent vegetation (9.9\%) and open water (59.1\%-void of vegetation). Daily water temperature in Pelican Lake during August through October 2009 ranged from 7.8 to $26.3{ }^{\circ} \mathrm{C}$ with a mean of $18{ }^{\circ} \mathrm{C}(\mathrm{SE}=0.64)$.

Exploratory interactions between age-0 bluegill and yellow perch

Age-0 yellow perch and bluegill were collected once from the study lakes in August or September (i.e., fall) using cloverleaf traps, placed in randomly chosen sites in nearshore areas (i.e., not patch type specific) of the lakes in 1-2 m of water. Sampling occurred later in the season to encompass a majority of the pelagic (larval) to littoral (juveniles) movement of individuals. Pelican Lake was sampled across 8 years (2004-2011), and the other lakes (Clear, Dewey, Watts, and West Long) were sampled 2 years (2008-2009). All fishes were preserved in $90 \%$ ethanol and returned to the laboratory. All fishes were identified and measured (total length, TL, in mm), and mean TL was calculated for each fall for each lake. Each three-lobed cloverleaf trap was constructed of galvanized 6.4-mm bar mesh, with three $12.7-\mathrm{mm}$-wide openings between lobes to accommodate entrance of small bluegill and yellow perch (Brown and St. Sauver 2002). Each lobe was 50 $\mathrm{cm}$ in diameter with $41 \mathrm{~cm}$ height. Cloverleaf traps have been previously and successfully used to assess stock contribution of age- 0 and age- 1 yellow perch in other populations (Brown and St. Sauver 2002) over a range of perch sizes (Longhenry 2006). Catch per unit effort (CPUE) was expressed as the mean number of age-0 fish captured per trap night (i.e., day) for each lake during each fall.

\section{Habitat use}

A total of five sites (same sites were sampled across months) featuring diverse habitat patches were sampled during the fall (i.e., August, September, October) of 2009 in Pelican Lake. Sampling sites were selected based on the criterion that all habitat patches were within a 50-m radius to minimize spatial variation among samples. Habitat patches were categorized according to the type of vegetation ( $>90 \%$ relative frequency) as (1) Phragmites, (2) Scirpus, (3) Typha, or (4) open water (void of emergent vegetation and lacking submergent vegetation).

Age-0 bluegill and yellow perch were sampled using cloverleaf traps (dimensions previously described) that were checked twice daily (i.e., morning and evening crepuscular periods) for three consecutive days during mid-August, September, and October in 2009 to examine diel habitat use. One cloverleaf trap was placed in each habitat patch (mean depth $=1 \mathrm{~m}$, range $0.4-1.7 \mathrm{~m}$ ) across five sampling sites (4 patch types $\times 5$ sampling sites $=20$ traps). All captured fish were identified and enumerated, and a subsample of 200 fish per trap for each species was measured for total length (i.e., TL) to the nearest millimeter. Age-0 (versus age-1) bluegill and yellow perch were determined using methods previously described. Catch per unit effort (CPUE) was expressed as the mean number of age-0 fish captured per trap hour.

\section{Diets}

Digestive tracts were removed from a minimum of 10 age- 0 bluegill and yellow perch per habitat patch each month within Pelican Lake during 2009 and stored in $90 \%$ ethanol. Individuals were randomly selected from diel periods (i.e., day and night), because determining specific consumption times (day vs. night feeding) is challenging due to variability in gastric evacuation rates among different prey types, temperatures, and body sizes (Booth 1990; Bromley 1994). Therefore, our results provide a broad examination of food habits across patch types. Individuals were also selected to encompass the range of sizes encountered in the samples where a minimum of two individuals were examined per five-millimeter-length category. 
Diet items were enumerated and identified to genus for all zooplankton taxa and order or family (i.e., Diptera) for macroinvertebrates and were measured to the nearest $0.01 \mathrm{~mm}$. Zooplankton taxon-specific lengthdry weight conversions were used to convert length to biomass $(\mu \mathrm{g})$. Biomass was then converted to wet weight using a dry mass-wet weight ratio of 0.10 for cladocerans and 0.12 for copepods (Cummins and Wuycheck 1971; Dumont et al. 1975; McCauley and Kalff 1981; Culver et al. 1985; Lynch et al. 1986). Similarly, macroinvertebrate lengths were used to estimate biomass with length-weight conversions (Smock 1980; Benke et al. 1999).

Statistical analyses

Pearson correlations were performed between fall mean TL (i.e., size) and fall mean CPUE (i.e., relative abundance) for both species among all lakes to examine potential interactions (i.e., intra- or interspecific). Because multiple pairwise comparisons were examined, a Holm's sequential Bonferroni adjustment was used to determine significance. All statistical analyses were performed in SAS (SAS Institute Inc. 2002). Some variables were $\log _{10}$-transformed to better approximate normality and achieve the requirements necessary for parametric analyses.

Relative prey importance for both age-0 bluegill and yellow perch in Pelican Lake was assessed for each habitat patch type during each month using the Costello (1990) graphical method as modified by Amundsen et al. (1996) where prey-specific abundance $\left(P_{i}\right)$ is calculated as

$P_{i}=\left(\frac{\sum S_{i}}{\sum S_{t i}}\right) \times 100$

where $P_{i}$ is the prey-specific abundance of prey $i, S_{i}$ the stomach content in dry weight comprised of prey $i$, and $S_{t i}$ the total stomach content in dry weight in only fishes containing prey $i$ in their stomach. Prey-specific abundance $\left(P_{i}\right)$ is then plotted as a function of the frequency of occurrence of each prey item to interpret feeding patterns. In a biplot of these variables, prey items located in the upper right-hand corners of the graph represent taxa with high frequency of occurrence and high prey-specific abundance and are characterized as important and dominant prey items. Prey items located in the lower left-hand corner of the graph reflect a low frequency of occurrence and low prey-specific abundance and represent less important and rare items (Amundsen et al. 1996).

Age-0 bluegill and yellow perch niche overlap (NO) in Pelican Lake was calculated for diets and habitat use according to Schoener's (1970) similarity index

$\mathrm{NO}=1-0.5 \sum\left|p_{i}-q_{i}\right|=\sum \min \left(p_{i}-q_{i}\right)$

where $p_{i}$ is the proportion of the population (or diet item) of a species (i.e., bluegill) in the $i$ th patch type and $q_{i}$ is the proportion of the population (or diet item) of another species (i.e., yellow perch) in the same patch type. Relative abundance (CPUE) was used to examine habitat-niche overlap during diel periods (i.e., night and day) during each month. The average of the biomass percentages of diet items was used to examine diet niche overlap across habitat patches each month (Wallace 1981). Niche overlap values range from 0 to 1 , and values between 0.6 and 1 infer high niche overlap, values ranging between 0.3 and 0.6 indicate moderate niche overlap, and values below 0.3 suggest low levels of niche overlap (Wallace 1981; Santamarina 1993).

\section{Results}

Exploratory interactions between age-0 bluegill and yellow perch

Age-0 bluegill fall mean TL was positively related to age-0 yellow perch fall mean TL $(r=0.73, P<0.01$; Fig. 1) across a spatiotemporal scale. In addition, age0 yellow perch mean TL was negatively related to age0 bluegill mean CPUE ( $r=-0.62, P=0.01$; Fig. 1 ). Fall age- 0 yellow perch mean CPUE was not related to fall age- 0 bluegill mean TL $(r=-0.10, P=0.72)$ or CPUE ( $r=0.19, P=0.49)$. Fall age-0 bluegill mean TL was not related to fall age-0 bluegill CPUE ( $r=$ $-0.37, P=0.16$ ) nor was fall age-0 yellow perch mean TL related to fall age-0 yellow perch CPUE $(r=-0.32, P=0.25)$.

Diets

Diets from 122 age-0 bluegill and 124 age- 0 yellow perch were examined in Pelican Lake. A total of nine diet items were dominant and most important to age- 0 

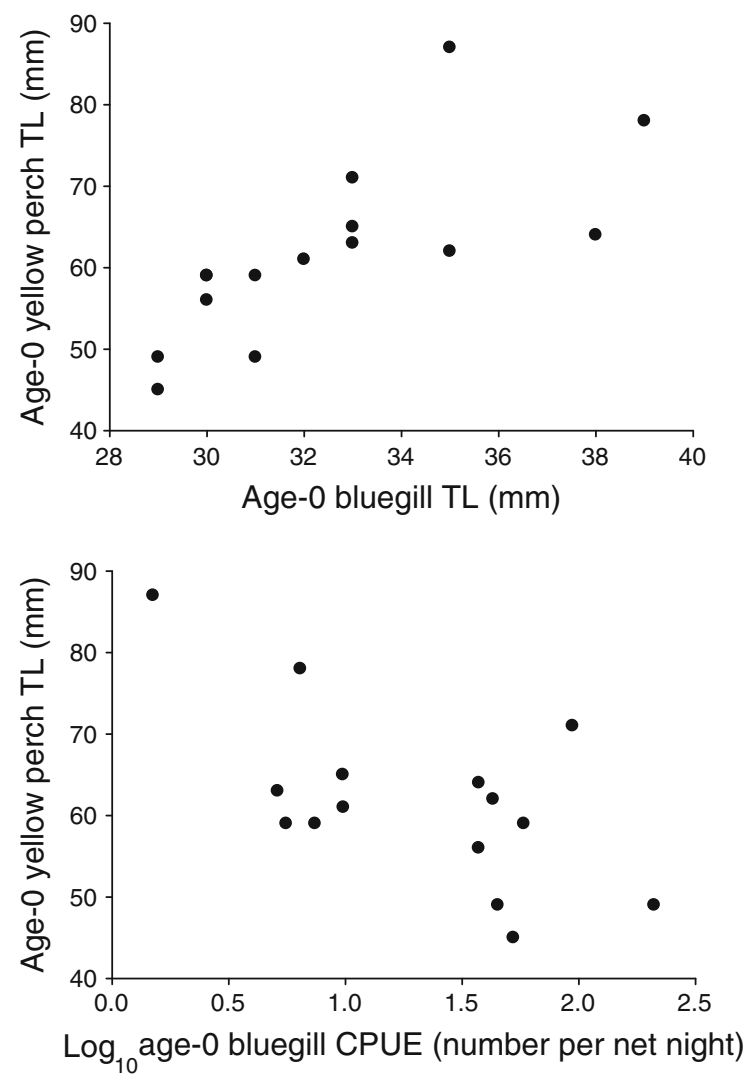

Fig. 1 Mean age- 0 bluegill TL ( $\mathrm{mm}$ ) in relation to mean age-0 yellow perch TL $(\mathrm{mm})$ for 15 lake-years in five Nebraska Sandhill lakes (top two lake-years are presented with yellow perch $\mathrm{TL}=59$ and bluegill $\mathrm{TL}=30$; no age- 0 yellow perch were sampled in one lake-year). Mean age-0 yellow perch TL $(\mathrm{mm})$ plotted as a function of $\log _{10}$-transformed bluegill mean number per trap night (CPUE) for 15 lake-years in Nebraska Sandhill lakes (bottom)

bluegill within each patch type among the months examined, of which four were zooplankton and five were benthic macroinvertebrates. Age-0 bluegill diets revealed a generalized feeding strategy during August across patch types with Chironomidae (open and Typha) and Bosmina (Phragmites, Scirpus, and Typha) prey types as the dominant and most important prey items during this month (Fig. 2). September age0 bluegill diets appeared to shift to a more specialized feeding strategy with fewer dominant and important prey items (except for Chironomidae in open patches; Fig. 2). Lastly, diets of age-0 bluegill in October were similar to those in August as a generalized feeding strategy was observed, with Chironomidae (Scirpus and Typha) and Chydorus (open) as the most dominant and important diet items (Fig. 2). Other diet items included Ceriodaphnia, Daphnia, Cyclops, Diaptomus, copepod nauplii, rotifers, Diaphanasoma, Ephemeroptera, Trichoptera, Coleoptera, Odonota, Plecoptera, and Ostracoda.

A total of six diet items were dominant and most important to age-0 yellow perch within each patch type among the months examined, of which four were zooplankton and only two were benthic macroinvertebrates. Age- 0 yellow perch diets in August revealed an apparent specialized feeding strategy with Chironomidae (open) and Bosmina (Phragmites) prey items as the dominant and most important prey items during this month (Fig. 3). No overall feeding strategy emerged during September with age-0 yellow perch in open and Phragmites patches exhibiting a more specialized feeding strategy and those sampled in Scirpus and Typha patches showing a more generalized feeding strategy (Fig. 3). The most important and dominant prey items in September included Chydorus (Phragmites) and amphipods (Scirpus). October age-0 yellow perch diets followed a more generalized feeding strategy across patch types with Chydorus (open and Phragmites) remaining as an important and dominant prey type (Fig. 3). Other diet items included Ceriodaphnia, Daphnia, Cyclops, Diaptomus, Diaphanasoma, Trombidiformes, Ephemeroptera, Trichoptera, Hemiptera, Odonota, Plecoptera, Ostracoda, and Hirudinea.

\section{Habitat and diet overlap}

Habitat overlap between age-0 bluegill and yellow perch was high during daytime in August (0.74), September (0.80), and October (0.64), with both species primarily utilizing vegetated patches as opposed to open patches. However, nighttime habitat overlap was moderate during August (0.45) and September (0.52), and high during October (0.81) with both species again using primarily vegetated habitat patches. Diet overlap among patch types was high or moderate in open patches across months corresponding to lower relative abundances of age- 0 bluegill and yellow perch, but generally low within emergent vegetation patch types (except Phragmites in August and Typha in October-moderate) for both species (Table 1). 


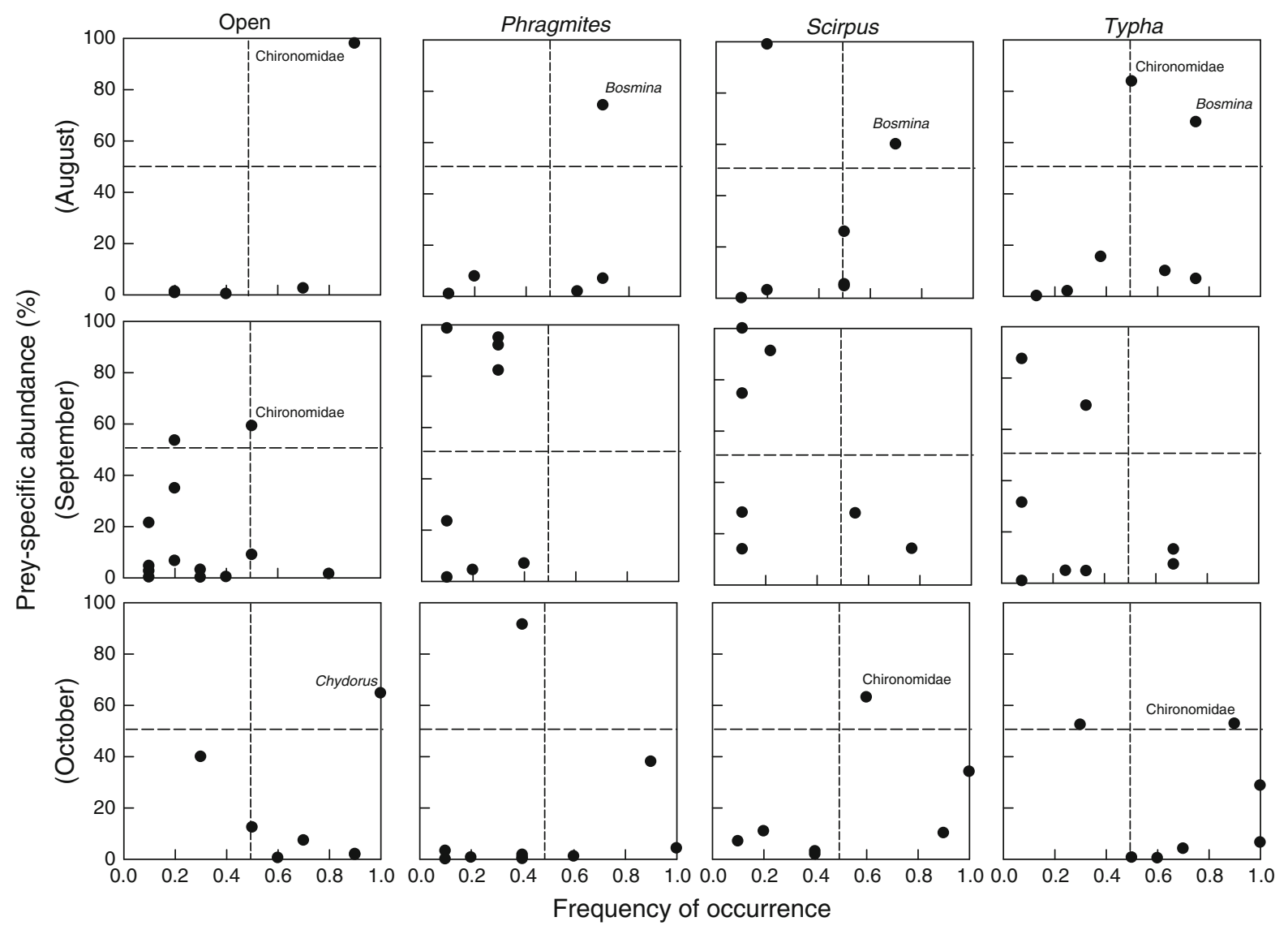

Fig. 2 Graphical analysis of age-0 bluegill diets in Pelican Lake, Nebraska, during August, September, and October of 2009 across four different habitat patch types (open, Phragmites, Scirpus, and Typha). Only dominant and most important

\section{Discussion}

By taking a mensurative approach, we were able to evaluate potential interactions of age- 0 bluegill and yellow perch within five Sandhill lakes and examine in more detail the relationship between these two species for food and habitat resources within one Sandhill lake. More evidence supports the hypothesis that competition for food resources may exist between age-0 bluegill and yellow perch in contrast to our initial hypotheses. Yellow perch growth rates may be negatively affected by the presence of bluegill because yellow perch may have to consume higher proportions of less profitable prey items (such as zooplankton) compared to systems where bluegill are absent or exist in low densities (Fig. 4). Eurasian perch also shifted feeding patterns to a diet prey items are labeled (upper right-hand corners). See text for more details on the methods used for calculating and interpreting the graphical technique presented in this figure

higher in zooplankton compared to macroinvertebrates when in sympatry with a species closely related to bluegill (pumpkinseed, Lepomis gibbosus; Fobert et al. 2011). Similarly, competition has been demonstrated between yellow perch and pumpkinseed where yellow perch were inferior to pumpkinseed when competing for prey resources (Hanson and Leggett 1985). Pumpkinseeds were able to feed primarily on macroinvertebrates and yellow perch on zooplankton in the presence of each other (Hanson and Leggett 1985). In addition, Schoenebeck and Brown (2010) also inferred that competition may exist between adult bluegill and yellow perch for prey resources.

We found a negative relationship between age- 0 yellow perch growth and age-0 bluegill abundance over a spatiotemporal scale in Nebraska Sandhill 


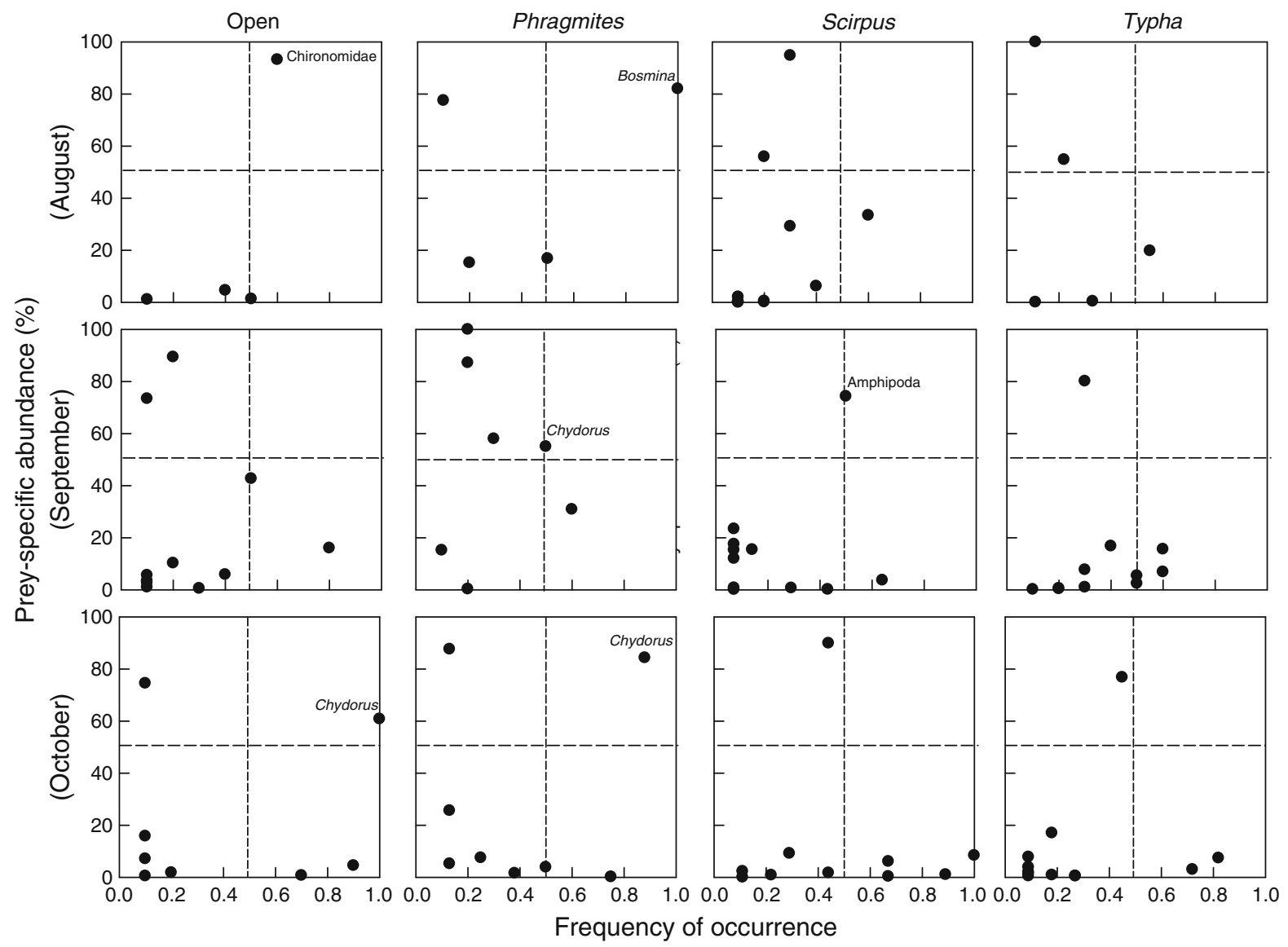

Fig. 3 Graphical analysis of age-0 yellow perch diets in Pelican Lake, Nebraska, during August, September, and October of 2009 across four different habitat patch types (open, Phragmites, Scirpus, and Typha). Only dominant and most important

Table 1 Schoener's diet overlap indices between age- 0 bluegill and yellow perch in Pelican Lake, Nebraska, during August, September, and October

\begin{tabular}{llll}
\hline & August & September & October \\
\hline Open & 0.996 & 0.724 & 0.441 \\
Phragmites & 0.568 & 0.046 & 0.087 \\
Scirpus & 0.091 & 0.194 & 0.051 \\
Typha & 0.299 & 0.223 & 0.451 \\
\hline
\end{tabular}

lakes. Yellow perch growth rates in our study may be negatively affected due to the higher contribution of zooplankton in their diets compared to other studies that demonstrate a diet primarily comprised of macroinvertebrates (more energetically profitable than zooplankton) at a similar size (Whiteside et al. 1985; Wu and prey items are labeled (upper right-hand corners). See text for more details on the methods used for calculating and interpreting the graphical technique presented in this figure

Culver 1992; Graeb et al. 2006). We anticipated that yellow perch diets would predominantly consist of macroinvertebrate prey items as opposed to zooplankton prey items based on the size $($ mean $=47 \mathrm{~mm})$ of fish sampled at the time of our study and typical ontogenetic diet shift from zooplankton to macroinvertebrates reported elsewhere (typically 30-35 mm, Pycha and Smith 1955; Ney and Smith 1975; Whiteside et al. 1985; Wu and Culver 1992; Roseman et al. 1996). Yellow perch also hatch earlier than bluegill, giving them priority to capitalize on resources before the arrival of bluegill (Kaemingk et al. 2012) and allows yellow perch to obtain a larger size (not as gape limited as bluegill) to consume macroinvertebrates earlier than bluegill. Finally, Graeb et al. (2006) experimentally demonstrated that yellow perch positively selected benthic macroinvertebrates at sizes observed in our 




Fig. 4 Conceptual model of age-0 bluegill and yellow perch in multiple late summer or fall scenarios (i.e., allopatric and sympatric populations) and their potential respective diets that can ultimately impact growth rates (i.e., response variable).

study and negatively selected and avoided zooplankton prey items.

Diet overlap between bluegill and yellow perch was rarely high across habitat patch types within each month examined. Evidence of high diet overlap only occurred within the open-water patch types, which also contained the lowest abundance of age- 0 bluegill. Both of these species consumed Chironomidae during the period of highest diet overlap (August). Lower abundances of bluegill in open-water patches may allow access to more profitable prey items such as Chironomidae for yellow perch, which in the presence of high bluegill abundance may resort to feeding on less profitable prey items such as zooplankton, with a resulting deduction in growth rates (Hayes and Taylor 1990; Lott et al. 1996) as found in this study. During periods of low diet overlap (most often), bluegill typically consumed more macroinvertebrates compared to yellow perch. In contrast, habitat overlap was generally high during the daytime and moderate during nighttime (except for high overlap during October). We suspect that habitat overlap was not higher during all periods because yellow perch utilized open-water patches more often than bluegill; however, both species frequently used emergent vegetation patches.

Growth rates of age- 0 yellow perch in the Nebraska Sandhill lakes also appear to be compromised compared to other systems. Age-0 yellow perch mean length during September in Pelican Lake (mean $=56 \mathrm{~mm}$,
Bluegill growth rates remain largely unaffected by the presence of yellow perch; however, yellow perch growth rates respond negatively to the presence of bluegill due to a shift in their diet (from macroinvertebrates to zooplankton)

range 45-65 mm; 2004-2011) is substantially smaller (50\% smaller) than age-0 yellow perch mean length observed in South Dakota glacial lakes at this time (East Krause, Middle Lynn, Lardy, $100 \mathrm{~mm}$ ), despite the Nebraska fish typically hatching 2 weeks earlier (Kaemingk et al. 2011; VanDeHey 2011). These South Dakota glacial lakes also contain much lower densities of age-0 bluegill compared to Nebraska Sandhill lakes (VanDeHey 2011). Clear Lake, which contained the lowest abundance of age- 0 bluegill in all the lakes sampled in this study, had the largest mean age- 0 yellow perch length $(87 \mathrm{~mm})$, which was closer to the observed lengths in these South Dakota glacial lakes. A majority of age-0 yellow perch mean lengths observed in this study were more comparable to those observed in west-central Minnesota lakes (Blackwell, Brophy, Freeborn, Louise), which also contained densities of bluegill comparable to those in Nebraska Sandhill lakes (Fullhart 2000).

As previously mentioned, more evidence from this study supports the hypothesis that competition may exist between age- 0 bluegill and yellow perch for food resources as opposed to habitat resources. However, our study was unable to identify whether this competition was primarily driven by interference or exploitative interactions. We hypothesize that these interactions were primarily exploitative for several reasons. First, we would expect low habitat overlap between the two species if one species was more 
aggressive than the other, which was not observed in our study. Second, age-0 bluegill abundances are typically much higher in Pelican Lake compared to age-0 yellow perch (Jolley 2009), thus giving bluegill a potential density advantage for prey resources. Finally, Hanson and Leggett (1985) concluded that competition between yellow perch and pumpkinseed was likely exploitative as no antagonistic behavior was detected. However, because we chose to take a mensurative approach, we could not determine the mode of competition (interference vs. exploitative) between these species. Thus, future studies should examine this relationship between age- 0 bluegill and yellow perch via a manipulative approach to gain more information on the magnitude and ultimate mechanism for competition.

Acknowledgments We thank D. Abler, A. Andrews, B. Graff, J. Harris, J. Jolley, P. McKenna, A. Rodgers, and K. Stahr for assistance in the field and laboratory. M. Lindvall and Valentine National Wildlife Refuge provided access to Pelican Lake. D. Graham, D. Krueger, Z. Brashears, and the Valentine State Fish Hatchery provided substantial assistance. Thanks to $\mathrm{C}$. A. Hayer, D. Dembkowski, T. Rapp, J. Breeggemann, D. Deslauriers, M. Grey (as part of the SDSU Comprehensive Ecology and Fisheries Discussion Group), M. Weber, and two anonymous reviewers for reviewing earlier drafts of this manuscript. Funding for this project was provided by the Nebraska Game and Parks Commission through Federal Aid in Sport Fish Restoration Project F-118-R.

\section{References}

Amundsen PA, Gabler HM, Staldvik FJ (1996) A new approach to graphical analysis of feeding strategy from stomach contents data-modification of the Costello (1990) method. J Fish Biol 48:607-614

Benke AC, Huryn AD, Smock LA, Wallace JB (1999) Lengthmass relationships for freshwater macroinvertebrates in North America with particular reference to the southeastern United States. J N Am Benthol Soc 18:308-343

Bergman E (1990) Effects of roach Rutilus rutilus on two percids, Perca fluviatilis and Gymnocephalus cernua: importance of species interactions for diet shifts. Oikos 57:241-249

Booth DJ (1990) Effect of water temperature on stomach evacuation rates, and estimation of daily food intake of bluegill sunfish (Lepomis macrochirus rafinesque). Can J Zool 68:591-595

Bromley PJ (1994) The role of gastric evacuation experiments in quantifying the feeding rates of predatory fish. Rev Fish Biol Fisher 4:36-66

Brown ML, St. Sauver TS (2002) An assessment of yellow perch, Perca flavescens, stocking contributions in eastern South Dakota lakes. Fish Manag Ecol 9:225-234
Carpenter SR (1996) Microcosm experiments have limited relevance for community and ecosystem ecology. Ecology 77:677-680

Carpenter SR (1999) Microcosm experiments have limited relevance for community and ecosystem ecology: reply. Ecology 80:1085-1088

Connell JH (1983) On the prevalence and relative importance of interspecific competition: evidence from field experiments. Am Nat 122:661-696

Costello MJ (1990) Predator feeding strategy and prey importance: a new graphical analysis. J Fish Biol 36:261-263

Culver DA, Boucherle MM, Bean DJ, Fletcher JW (1985) Biomass of freshwater crustacean zooplankton from lengthweight regressions. Can J Fish Aquat Sci 42:1380-1390

Cummins KW, Wuycheck JC (1971) Caloric equivalents for investigations in ecological energetics. Mitteilung/internationale vereinigung fuer theoretische und angewandte limnologie; no. 18. Schweizerbart, Stuttgart

Drenner RW, Mazumder A (1999) Microcosm experiments have limited relevance for community and ecosystem ecology: comment. Ecology 80:1081-1085

Dumont HJ, Velde I, Dumont S (1975) The dry weight estimate of biomass in a selection of cladocera, copepoda and rotifera from the plankton, periphyton and benthos of continental waters. Oecologia 19:75-97

Fobert E, Fox MG, Ridgway M, Copp GH (2011) Heated competition: how climate change will affect non-native pumpkinseed Lepomis gibbosus and native perch Perca fluviatilis interactions in the U.K. J Fish Biol 79: $1592-1607$

Fullhart HG (2000) Biology of age-1 and older yellow perch in west-central Minnesota lakes: MS Thesis, South Dakota State University, Brookings, SD, USA

Gabler HM, Amundsen PA (1999) Resource partitioning between siberian sculpin (Cottus poecilopus heckel) and atlantic salmon parr (Salmo salar l.) in a sub-arctic river, northern Norway. Ecol Freshw Fish 8:201-208

Graeb BDS, Mangan MT, Jolley JC, Wahl DH, Dettmers JM (2006) Ontogenetic changes in prey preference and foraging ability of yellow perch: insights based on relative energetic return of prey. T Am Fish Soc 135:1493-1498

Hanson JM, Leggett WC (1985) Experimental and field evidence for inter- and intraspecific competition in two freshwater fishes. Can J Fish Aquat Sci 42:280-286

Hayes DB, Taylor WW (1990) Reproductive strategy in yellow perch (Perca flavescens): effects of diet ontogeny, mortality, and survival costs. Can J Fish Aquat Sci 47:921-927

Hearn WE (1987) Interspecific competition and habitat segregation among streamdwelling trout and salmon-a review. Fisheries 12:24-31

Hixon MA, Jones GP (2005) Competition, predation, and density-dependent mortality in demersal marine fishes. Ecology 86:2847-2859

Holbrook SJ, Schmitt RJ (2002) Competition for shelter space causes density-dependent predation mortality in damselfishes. Ecology 83:2855-2868

Jang MH, Joo GJ, Lucas MC (2006) Diet of introduced largemouth bass in Korean rivers and potential interactions with native fishes. Ecol Freshw Fish 15:315-320

Jolley JC (2009) Recruitment of bluegill and yellow perch in Nebraska Sandhills lakes: integrating multiple life stages: 
PhD Dissertation, South Dakota State University, Brookings, SD, USA

Kaemingk MA, Jolley JC, Willis DW, Graeb BDS (2011) Exploring spatial distributions of larval yellow perch Perca flavescens, bluegill Lepomis macrochirus and their prey in relation to wind. J Fish Biol 78:1132-1151

Kaemingk MA, Jolley JC, Willis DW, Chipps SR (2012) Priority effects among young-of-the-year fish: reduced growth of bluegill sunfish (Lepomis macrochirus) caused by yellow perch (Perca flavescens)? Freshwat Biol 57:654-665

Kennedy GJA, Strange CD (1986) The effects of intra- and inter-specific competition on the survival and growth of stocked juvenile Atlantic salmon, Salmo salar L., and resident trout, Salmo trutta L., in an upland stream. J Fish Biol 28:479-489

Longhenry CM (2006) Yellow perch production in semi-permanent wetlands in Eastern South Dakota and evaluation of a new chemical marking tool for juvenile yellow perch: MS Thesis, South Dakota State University, Brookings, SD, USA

Lott JP, Willis DW, Lucchesi DO (1996) Relationship of food habits to yellow perch growth and population structure in South Dakota lakes. J Freshw Ecol 11:27-37

Ludsin SA, DeVries DR (1997) First-year recruitment of largemouth bass: the interdependency of early life stages. Ecol Appl 7:1024-1038

Lynch M, Weider LJ, Lampert W (1986) Measurement of the carbon balance in daphnia. Limnol Oceanogr 31:17-33

McCauley E, Kalff J (1981) Empirical relationships between phytoplankton and zooplankton biomass in lakes. Can J Fish Aquat Sci 38:458-463

Mills MD, Rader RB, Belk MC (2004) Complex interactions between native and invasive fish: the simultaneous effects of multiple negative interactions. Oecologia 141:713-721

Mittelbach GG (1981) Foraging efficiency and body size: a study of optimal diet and habitat use by bluegills. Ecology 62:1370-1386

Mittelbach GG (1984) Predation and resource partitioning in two sunfishes (Centrarchidae). Ecology 65:499-513

Mittelbach GG (1988) Competition among refuging sunfishes and effects of fish density on littoral zone invertebrates. Ecology 69:614-623

Ney JJ, Smith LL (1975) First-year growth of the yellow perch, Perca flavescens, in the Red Lakes, Minnesota. T Am Fish Soc 104:718-725

Paukert CP, Willis DW, Holland RS (2002) Sample size requirements for in situ vegetation and substrate classifications in shallow, natural Nebraska lakes. N Am J Fish Manage 22:1329-1333

Persson L (1983a) Food consumption and competition between age classes in a perch Perca fluviatilis population in a shallow eutrophic lake. Oikos 40:197-207
Persson L (1983b) Food consumption and the significance of detritus and algae to intrascpecific competition in roach Rutilus rutilus in a shallow eutrophic lake. Oikos 41: $118-125$

Persson L (1983c) Effects of intra- and interspecific competition on dynamics and size structure of a perch Perca fluviatilis and a roach Rutilus rutilus population. Oikos 41:126-132

Pycha RL, Smith LL (1955) Early life history of the yellow perch, Perca flavescens (mitchell), in the Red Lakes, Minnesota. T Am Fish Soc 84:249-260

Raborn SW, Miranda LE, Driscoll MT (2004) Diet overlap and consumption patterns suggest seasonal flux in the likelihood for exploitative competition among piscivorous fishes. Ecol Freshw Fish 13:276-284

Roseman EF, Mills EL, Forney JL, Rudstam LG (1996) Evaluation of competition between age-0 yellow perch (Perca flavescens) and gizzard shad (Dorosoma cepedianum) in Oneida Lake, New York. Can J Fish Aquat Sci 53:865-874

Santamarina J (1993) Feeding ecology of a vertebrate assemblage inhabiting a stream of NW Spain (Riobo; Ulla basin). Hydrobiologia 252:175-191

Santucci VJ, Wahl DH (2003) The effects of growth, predation, and first-winter mortality on recruitment of bluegill cohorts. T Am Fish Soc 132:346-360

Schoenebeck CW, Brown ML (2010) Potential importance of competition, predation, and prey on yellow perch growth from two dissimilar population types. Prairie Nat 42:32-37

Schoener TW (1970) Nonsynchronous spatial overlap of lizards in patchy habitats. Ecology 51:408-418

Smock LA (1980) Relationships between body size and biomass of aquatic insects. Freshwat Biol 10:375-383

Tilman D (1987) The importance of the mechanisms of interspecific competition. Am Nat 129:769-774

VanDeHey JA (2011) Influence of gizzard shad on fish community ecology in northeastern South Dakota glacial lakes: PhD Dissertation, South Dakota State University, Brookings, SD, USA

Wallace RK (1981) An assessment of diet-overlap indexes. T Am Fish Soc 110:72-76

Wheeler AP, Allen MS (2003) Habitat and diet partitioning between shoal bass and largemouth bass in the Chipola River, Florida. T Am Fish Soc 132:438-449

Whiteside MC, Swindoll CM, Doolittle WL (1985) Factors affecting the early life history of yellow perch Perca flavescens. Environ Biol Fish 12:47-56

Wu L, Culver DA (1992) Ontogenetic diet shift in Lake Erie age-0 yellow perch (Perca flavescens): a size-related response to zooplankton density. Can J Fish Aquat Sci 49:1932-1937 